\section{Leadership wrangle forces Salk Institute restructuring}

[SAN DIEGO] The Salk Institute in La Jolla, California, is restructuring its administration amid staff divisions over the leadership of the world-renowned biology research centre.

The institute's board met on 4 August to consider recommendations by a management consultant who was brought in after Thomas Pollard was relieved of his role as chief executive officer in February. Pollard remains president of the institute, with board chairman Frederick Rentschler serving as interim chief executive.

This change and the subsequent interim arrangement have left the faculty deeply divided, insiders say. According to one of them, one-third of the staff support Pollard, one-third do not and the remainder are indifferent.

Some staff members fear that if Pollard leaves or is ousted as president, the Salk Institute may enter a period ofleadership vacuum — a situation that has harmed the institute in the past.

"We may find it difficult to find anyone outside the institute willing to take on the job, given the past history," says Ian Trowbridge, a cell biologist and senior faculty member who supports Pollard.

Trowbridge says that what he terms Pollard's "demotion" was a "misstep" by the board.

Bartholomew Sefton, a molecular biologist and senior faculty member, says: "We are in disarray at the moment, regarding who is leading the institute.

"Authority is unclear. As a result, it is hard to make decisions that involve a lot of money."

Rentschler, the retired chief executive of a food corporation, seeks to minimize the impression of strife at the institute, saying he is unaware of any deep concern among the faculty members.

In a telephone interview from his Montana ranch, he praised the management consultant, Edward Hamilton of the Los Angeles firm Hamilton, Rabinovitz and Alschuler, for "a terrific report" that "grabs the essence of the Salk Institute".

Rentschler says that the board's executive committee will now begin to prioritize and implement Hamilton's recommendations. "The report has the potential to put the Salk Institute on a strong foundation in the next millennium," says Rentschler, who declined to release its contents.

All sides of the internal debate agreed about the report's potential, but some staff and a member of the executive committee have said that implementing change will be a

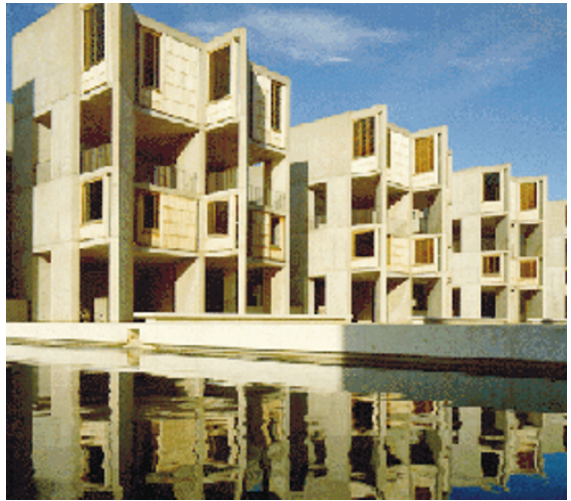

Trouble at the top: 'temperamental' senior staff

tough job, made more difficult by the dynamics of the institute's faculty.

The 50 active members of faculty at the institute include some of the world's finest biologists. However, the high self-esteem of some of these individuals has contributed to the current management difficulties, say insiders.

Since Pollard lost the chief executive role, no explanation has been offered to staff or the public. Asked why he lost the position, Pollard says: "It is too complicated to explain. It is best to wait until the governance issue is straightened out."

A cell biologist and member of the National Academy of Sciences, Pollard was chairman of cell biology at Johns Hopkins University in Baltimore, Maryland before taking over at the Salk three years ago. Since arriving, he has seen its annual philanthropic contributions rise to $\$ 25.5$ million, taking its endowment above $\$ 100$ million for the first time.

Despite his achievements, some senior faculty members remain unhappy. Interviews with a number of staff produced no major concerns about Pollard's performance, but a series of disputes that several faculty members describe as "petty". Some senior staff, for instance, are upset that most innovation grants were going to junior staff.

"It is unclear to anyone how to handle temperamental faculty," says Sefton, who has served as head of the faculty for part of his 25 years at the institute. "I'm not sure I have an idea how to either."

The dispute came to a head early this year, when a handful of senior faculty members called Rentschler threatening to quit if he didn't make an executive change, according to statements he made at a faculty luncheon. This prompted Rentschler to step in as interim chief executive.

Rex Dalton have made the Salk Institute difficult to manage.
Canadian report urges universities to make research earn its keep

[MONTREAL] Canadian universities and research councils are under pressure to commercialize research results or risk losing federal grants, following a critical report to prime minister Jean Chrétien.

The report, prepared by a subpanel of Chrétien's Advisory Council on Science and Technology, calls for a "bold new approach" to the commercialization of university research. It claims that existing practice is "resulting in lost investment opportunities, jobs and social benefits".

The report, Public Investments in University Research: Reaping the Benefits, proposes that all recipients of federal research funds should make a commitment to obtain the greatest possible benefit for Canada whenever their research produces a commercial gain - or risk losing further funds.

It suggests that universities should identify "innovation" as their fourth mission, in addition to teaching, research and community service. Innovation is defined as "the process of bringing new goods and services to market, or the result of that process".

The subpanel also proposes that funding bodies include innovation in their mission statements and use it as a criterion for awarding research grants.

Although science advisers have not always had much success at influencing policy in Canada, observers believe that parts of this report are likely to be implemented, as it reflects current government thinking.

The subpanel says that Canada lacks a coherent policy for safeguarding intellectual property at its universities. It suggests that the government should provide additional resources to help universities strengthen their commercialization capabilities. It also calls for a review of tax policy to encourage innovation, and an overall increase in federal funding for university research.

Some academic researchers were quick to attack what they see as the report's overemphasis on commercial values.

"They're trying to foist on the universities something which belongs in a different culture," says John Polanyi, a 1986 Nobel Prizewinner in chemistry. "They really don't seem to be aware of the fact that they are asking for something which, if it were given to them, would do damage to the universities."

But David Strangway, a former university president who now heads the Canada Foundation for Innovation, says: “I don't think very many universities are actually going to change their mission statements, but you may see them getting more [commercially] aggressive". David Spurgeon 